\title{
Lupinus elegans KUNTH ASSISTED MIGRATION IN COMMON GARDEN FIELD TESTS
}

\author{
MIGRACIÓN ASISTIDA DE Lupinus elegans KUNTH EN ENSAYOS DE JARDÍN COMÚN EN CAMPO
}

\author{
José C. Soto-Correa ${ }^{1,2}$, Roberto Lindig-Cisneros ${ }^{3}$ y Cuauhtémoc Sáenz-Romero ${ }^{1 \star}$
}

\begin{abstract}
${ }^{1}$ Instituto de Investigaciones Agropecuarias y Forestales, Universidad Michoacana de San Nicolás de Hidalgo (IIAF-UMSNH). Km 9.5 Carr. Morelia-Zinapécuaro. 58880, Tarímbaro, Michoacán. ${ }^{2}$ Current address: Universidad Rey Juan Carlos. Calle Tulipán s/n. 28933. Móstoles, Madrid, España. ${ }^{3}$ Centro de Investigaciones en Ecosistemas, Universidad Nacional Autónoma de México (CIEco-UNAM). Antigua Carretera a Pátzcuaro No. 8701, Colonia Ex-Hacienda de San José de La Huerta. 58190, Morelia, Michoacán.
\end{abstract}

${ }^{*}$ Corresponding author (csaenzromero@gmail.com)

\section{SUMMARY}

Lupinus elegans is a species used in ecological restoration and agroforestry programs, because it is tolerant to stress and fixes nitrogen. Genetic variation in quantitative traits was studied in six populations of L. elegans collected along an altitudinal gradient (2312 to $2885 \mathrm{~m}$ ) in the Mil Cumbres region, east-central Michoacán state, México. Provenance tests were planted at 2600 and $2800 \mathrm{~m}$ altitude in two common garden field trials. Tests aimed to evaluate the performance at a different altitude than the site of the seed source, simulating an altitudinalassisted migration. Survival, plant height growth and aerial biomass were measured. For each provenance and experimental sites, climatic variables were estimated for contemporary climate (average 19611990 ) and future climate (decade centered in 2030 , by averaging six model scenarios). It was estimated that by the year 2030 there will be, on average, an increment of $1.4^{\circ} \mathrm{C}$ in mean annual temperature, an increase of 518 degree-days $>5{ }^{\circ} \mathrm{C}$ (DD5), a $90 \mathrm{~mm}$ decrease in mean annual precipitation (MAP) (-7.3\% of contemporary MAP), and a 0.0077 increase in an aridity index (DD5 $\left.{ }^{0.5} / \mathrm{MAP}\right)$. An ANOVA for each site revealed that in the higher altitude site $(2800 \mathrm{~m})$ populations exhibited a pronounced pattern of genetic differentiation $(P=0.0001)$, in which plant height and biomass are associated with the transfer distance between their place of origin and the experimental site. This distance can be expressed in difference in altitude, mean annual temperature, or aridity index. At the site at higher altitude, plants originated from populations growing at higher altitudes were taller and had more biomass than those originated grown at lower altitudes $\left(R^{2} \geq 0.85, P \leq 0.0302\right)$. In contrast, in the lower altitude site $(2600 \mathrm{~m})$, although there were nearly significant differences $(P \leq 0.0615)$ between populations for all of the variables, there was no clinal pattern. In general, the populations grew less when they were moved away from their original climate: those from the higher altitudes grew less in the $2600 \mathrm{~m}$ site, and those from the lower altitudes grew less in the $2800 \mathrm{~m}$ site. This indicates that climate change will likely induce less growth in several populations, thus it is recommended to promote gradual assisted migration.

Index words: Lupinus elegans, climate change, assisted migration, provenances, altitudinal shift, quantitative genetic variation.

\section{RESUMEN}

Lupinus elegans es una especie que se ha utilizado en la restauración ecológica y programas agroforestales, ya que es tolerante al estrés y fija nitrógeno. La variación genética en los rasgos cuantitativos se estudió en seis poblaciones de L. elegans originadas a lo largo de un gradiente altitudinal $(2312-2885 \mathrm{~m})$ en la región de Mil Cumbres,
Estado de Michoacán, el centro-este de México. Se plantaron ensayos de procedencias a 2600 y 2800 m de altitud, en dos ensayos de jardín común en campo. Los ensayos pretendieron evaluar el rendimiento a una altitud diferente del lugar de origen de la fuente de semilla, para simular una migración asistida altitudinal. Se midió la supervivencia, crecimiento en altura de planta y biomasa aérea. Para cada procedencia y sitio experimental, se estimaron variables climáticas para el clima contemporáneo (promedio 1961-1990) y el clima futuro (década centrada en el año 2030, con un promedio de seis modelos-escenarios). Se estima que para el año 2030 habrá, en promedio, un incremento de $1.4^{\circ} \mathrm{C}$ en la temperatura media anual, un aumento de 518 grados días $>$ $5{ }^{\circ} \mathrm{C}$ (DD5), una disminución de $90 \mathrm{~mm}$ de precipitación anual media (MAP) (-7.3 \% del MAP contemporánea), y un aumento de 0.0077 en un índice de aridez (DD5 $\left.{ }^{0.5} / \mathrm{MAP}\right)$. Un ANOVA para cada sitio reveló que en el sitio de mayor altitud $(2800 \mathrm{~m})$ las poblaciones mostraron un patrón pronunciado de diferenciación genética $(P=0.0001)$, en el que la altura de planta y la biomasa están asociadas con la distancia de transferencia entre su lugar de origen y el sitio experimental. Esta distancia se puede expresar como diferencia en altitud, en temperatura media anual, o en índice de aridez. En el sitio de ensayo a mayor altitud, las plantas de poblaciones originadas a mayor altitud tuvieron mayor altura de planta y biomasa que las plantas de las poblaciones originadas a menor altitud $\left(R^{2} \geq 0.85, P \leq 0.0302\right)$. En contraste, en el sitio de ensayo a una altitud más baja $(2600 \mathrm{~m})$, aunque hubo diferencias casi significativas $(P \leq 0.0615)$ entre las poblaciones para todas las variables, no hubo un patrón clinal. En general, las poblaciones crecieron menos cuando se movieron lejos de su clima original: las procedentes de mayores altitudes crecieron menos en el sitio de $2600 \mathrm{~m}$, y las procedentes de menores altitudes crecieron menos en el sitio de 2800 $\mathrm{m}$. Esto indica que el cambio climático muy probablemente va a inducir un menor crecimiento en varias poblaciones y que conviene practicar la migración asistida gradualmente.

Palabras clave: Lupinus elegans, cambio climático, migración asistida, procedencias, movimiento altitudinal, variación genética cuantitativa.

\section{INTRODUCTION}

Climatic models for México have predicted average increases in mean annual temperature of $1.5^{\circ} \mathrm{C}$ for the decade centered in the year $2030,2.3^{\circ} \mathrm{C}$ for 2060 and $3.7^{\circ} \mathrm{C}$ for 2090 , and decreases in precipitation of $6.7 \%, 9.0 \%$ and $18.2 \%$, respectively, relative to the reference period denominated "contemporary" 1961-1990 (Sáenz-Romero et al., 2010). This will create an adaptive lag between populations 
of timber and non-timber species and the environment for which they are adapted. That is, populations of forest species will be growing in a site with a climate that has been modified, and to which they are still not adapted.

In the climate change context, plant species will have basically three options: adapt, migrate or die (Aitken et al., 2008). Unfortunately, migration by natural mechanisms of seed dispersion and establishment of colonizers in new habitats is extremely slow, relative to the speed necessary for genotypes to maintain correspondence with environments for which they are adapted (MacLachlan et al., 2005; Pearson, 2006). The ability to adapt to new climates will depend on the amplitude of phenotypic plasticity and genetic diversity of each population. There is evidence that once this plasticity is exhausted, the populations enter a process of rapid decline (McDowell et al., 2008; Mátyás et al., 2010). Apparently, the only option will be human assistance to realign genotypes with environments to which they are adapted (Tchebakova et al., 2005). This has been called assisted migration, and consists of massive reforestation with plants grown from seeds collected in sites where the climate is similar to the climate that will occur in the future in the site to be reforested.

The populations of forest species distributed naturally along an altitudinal gradient tend to differentiate genetically as an adaptive mechanism in response to different selection intensities imposed by the environmental gradient (Rehfeldt, 1988; Benowicz et al., 2001; Oleskyn et al., 2001; Devall, 2009). For this reason, altitudinal gradients in mountain systems offer an excellent opportunity to study how genetically differentiated populations adapt to specific climatic conditions (Thomas, 2011).

Lupinus elegans Kunth is a legume found in pine-oak and conifer forests. Endemic to West-Central México, it is distributed at altitudes between 1800 and 3000 m (Sánchez, 1980; Dunn, 2001). It has been used in ecological reforestation and agroforestry programs because it creates favorable conditions for establishment of native tree, bush and herbaceous species of conifer forests. It is also tolerant to conditions of stress and fixes nitrogen (Lindig-Cisneros et al., 2007; Alvarado-Sosa et al., 2007). It has been shown that Lupinus elegans populations are genetically differentiated in neutral (or almost neutral) to selection traits as well as in quantitative traits (Lara-Cabrera et al., 2009), and these differences are expressed along altitudinal gradients (SotoCorrea et al., 2013). L. elegans has also been proposed as a nurse species providing a temporary canopy that protects Abies religiosa seedlings from extreme temperatures in reforesting disturbed sites at high altitudes (Blanco-García et al., 2011). This would be of extraordinary importance for ecological restoration of the Monarch Butterfly Biosphere
Reserve, where it will be necessary to carry out assisted migration of Abies religiosa populations (Sáenz-Romero et al., 2012a). For this reason, it is important to explore the possibility of assisting migration of an assemblage of species: $A$. religiosa and $L$. elegans. However, the potential of assisted migration of Lupinus elegans has not been tested.

This study aimed to: (a) Confirm the existence of genetic differentiation in terms of quantitative traits among Lupinus elegans populations growing along altitudinal gradients, and (b) Determine the performance of population genotypes (originated at different altitudes) when they are transferred to a different altitude (elevations higher or lower than their altitude of origin).

Our hypotheses were that: (a) There is genetic differentiation among populations along the altitudinal gradient, and (b) Populations grow less when they are moved away from the climate from which they originated and adapted.

\section{METHODS}

\section{Seed collection}

Open pollinated seeds were collected from 11 individuals of each of six natural Lupinus elegans stands along an altitudinal gradient, from 2312 to $2885 \mathrm{~m}$, in the Mil Cumbres region in east-central state of Michoacán, México (Table 1), from December 2008 to February 2009. The sites of origin where seeds were collected will be referred to as 'provenance', and the set of individuals from a provenance will be referred to as 'population', represented in the experiment by the plants originated from that population.

\section{Experimental design}

The seeds collected from the six populations were cleaned and scarified in the laboratory (immersion in $97 \% \mathrm{H}_{2} \mathrm{SO}_{4}$ Fermnt ${ }^{\circledR}$ for 30 min to soften the seed cover). Scarification was to assure germination after direct sowing at the experimental sites (Medina-Sánchez and Lindig-Cisneros, 2005).

The provenance trial was set up in two open sites in a natural mixed pine, oak and sacred fir forest (dominated by Pinus pseudostrobus and Abies religiosa), at two altitudes (2600 and $2800 \mathrm{~m}$ ), near the town La Mina and the scenic lookout Mil Cumbres, Michoacán (Table 1). Each site was fenced to prevent attack by animals, and weeds were eliminated. In each field site, two raised nursery beds made of a wooden frame $4.4 \mathrm{~m}$ long x 2 $\mathrm{m}$ wide $\mathrm{x} 0.5 \mathrm{~m}$ high were filled with pine-oak substrate extracted from a single representative site of the local mixed pine-oak-sacred fir forest at $2700 \mathrm{~m}$ altitude. Two bags of commercial substrate Creciroot ${ }^{\circledR}$ (coconut fiber 
base, charcoal, Agrolite and a slow-release fertilizer) was added to each raised bed.

The objective of establishing the raised nursery beds was to eliminate site variability due to soil conditions, since previous experiences revealed broad variability among sites, regardless of altitude, due to the history of disturbance of each site. The environment created by the raised beds is similar to that created in what is known as common garden tests.

In August 2010, scarified seeds from the six populations were planted directly in the common garden tests under an experimental design of randomized complete blocks, with 12 blocks in each site and five plants per plot. Seeds were planted in rows at a distance between seeds of $20 \times 20 \mathrm{~cm}$. Initially, three seeds were planted to obtain a single plant; if two or three emerged, the less vigorous plants were eliminated eight weeks after emergence, leaving 60 seedlings per population for evaluation at each site. Survival, height growth and aerial biomass were assessed when plants were 12 months old. Increase in seedling height was estimated as the difference between plant height at 12 months minus its height at two months of age; this eliminated to a large extent the maternal effect of seed size.

Aerial biomass was obtained by collecting the aerial part of all the surviving seedlings, which was dried in an oven (Felizaä, México) at $60{ }^{\circ} \mathrm{C}$ for $72 \mathrm{~h}$ (Sáenz-Romero et al., $2012 \mathrm{~b})$. The samples were weighed on a scale (Ohaus ${ }^{\circledR}$, 0.01 g precision, Canada).

\section{Climate modeling}

To find a possible relationship between growth variables and climate (contemporary and future) of either the provenances or the experimental sites, the contemporary climate variables (average of 30 years: 1961-1990) temperature and precipitation were estimated for each provenance and as a proxy for the experimental sites, and likewise for the aver- age of the decade centered in the year 2030 (hence referred simply as year 2030). The estimations were obtained by running spline climatic models, using the geographic coordinates and altitude of each provenance and experimental site (Crookston and Rehfeldt, 2011).

The spline model for contemporary climate was developed on the basis of monthly temperature means (low, median and high) and precipitation of approximately 4000 weather stations in México, southeastern USA, Guatemala, Belize and Cuba for the period 1961-1990 (Sáenz-Romero et al., 2010). Predictions for future climate are based on modeling data from the same weather stations, but with monthly means adjusted with predictions of the Intergovernmental Panel on Climate Change (IPCC Data Distribution Center: URL: http://www.ipcc-data.org/ Sáenz-Romero et al., 2010).

Estimations were made for six global circulation models (Canadian, Hadley and Geophysics of Fluid Dynamic), and two scenarios of greenhouse-effect gas emissions (A, high emissions, or pessimistic scenario; B, low emissions, or optimistic scenario), giving a total of six model-scenarios. Finally, an average was obtained of the six model-scenarios. The estimated variables were mean annual temperature (MAT, in ${ }^{\circ} \mathrm{C}$ ), mean annual precipitation (MAP, in $\mathrm{mm}$ ), annual degree-days $>5{ }^{\circ} \mathrm{C}$ (DD5, degree-days) and an annual aridity index (AAI $=\mathrm{DD} 5^{0.5} / \mathrm{MAP}$, index). The aridity index is closely related to species distribution and vegetation type (Rehfeldt, 2006; Rehfeldt et al., 2006).

Transfer distance (TD) in altitude and in climate values was derived from population movement from their original provenances to experimental sites, using the following formula (Leites et al., 2012):

$$
D_{i j}=S_{i}-P_{j}
$$

where $D_{i j}=$ transfer distance of the $j^{\text {th }}$ population transferred to the $i^{\text {th }}$ experimental site. $S_{i}=$ altitude $(\mathrm{m})$ or climate value (mean annual temperature, ${ }^{\circ} \mathrm{C}$; mean annual precipitation,

Table 1. Geographic location of tested Lupinus elegans populations and experimental sites.

\begin{tabular}{|c|c|c|c|c|}
\hline Population & Site & W Longitude & N Latitude & Altitude (m) \\
\hline 1 & Puerto Garnica & $100^{\circ} 49^{\prime} 25^{\prime \prime}$ & $19^{\circ} 39^{\prime} 58^{\prime \prime}$ & 2885 \\
\hline 2 & Puerto Garnica Cantiles & $100^{\circ} 49^{\prime} 46^{\prime \prime}$ & $19^{\circ} 40^{\prime} 49^{\prime \prime}$ & 2800 \\
\hline 3 & Mil Cumbres la Cruz & $100^{\circ} 45^{\prime} 59^{\prime \prime}$ & $19^{\circ} 37^{\prime} 20^{\prime}$ & 2650 \\
\hline 4 & San José de la Cumbre la Puerta & $100^{\circ} 51^{\prime} 31^{\prime \prime}$ & $19^{\circ} 39^{\prime} 51^{\prime \prime}$ & 2480 \\
\hline 5 & Mil Cumbres Caracol & $100^{\circ} 46^{\prime} 25^{\prime \prime}$ & $19^{\circ} 46^{\prime} 25^{\prime \prime}$ & 2480 \\
\hline 6 & San José de la Cumbre la Ciénaga & $100^{\circ} 51^{\prime} 28^{\prime \prime}$ & $19^{\circ} 39^{\prime} 15^{\prime \prime}$ & 2312 \\
\hline Experimental site 1 & Higher altitude & $100^{\circ} 45^{\prime} 45^{\prime \prime}$ & $19^{\circ} 37^{\prime} 31^{\prime \prime}$ & 2800 \\
\hline Experimental site 2 & Lower altitude & $100^{\circ} 46^{\prime} 00^{\prime \prime}$ & $19^{\circ} 37^{\prime} 75^{\prime \prime}$ & 2600 \\
\hline
\end{tabular}


$\mathrm{mm} ;>5^{\circ} \mathrm{C}$; annual aridity index) of the $i^{\text {th }}$ experimental site. $P_{j}=$ altitude $(\mathrm{m})$ or climate variable of the original site of the $j^{\text {th }}$ population.

\section{Statistical analysis}

To determine whether significant differences exist between populations, an analysis of variance was performed using Proc GLM in SAS (SAS, 2004), with the following statistical model:

$$
Y_{i j k l}=\mu+S_{i}+B_{j}\left(S_{i}\right)+P_{k}+S_{i} P_{k}+P_{k} B_{j}\left(S_{i}\right)+e_{i j k l}
$$

where: $Y_{i j k l}=$ observation; $\mu=$ effect of the general mean; $S_{i}=$ effect of the $i^{\text {th }}$ sitie; $B_{j}=$ effect of the $j^{\text {th }}$ block nested in the $i^{\text {th }}$ site; $P_{k}=$ effect of the $k^{\text {th }}$ population; $S_{i} P_{k}=$ effect of the $i k^{\text {th }}$ site by population interaction; $P_{k} B_{j}\left(S_{i}\right)=$ effect of the $k j^{\text {th }}$ population by block interaction nested in the $i^{\text {th }}$ site; $e_{i j k l}=$ error.

In addition, an analysis of variance was performed for each site using the following model:

$$
Y_{i j k}=\mu+B_{i}+P_{j}+B_{i} P_{j}+e_{i j k}
$$

where: $Y_{i j k}=$ observation; $\mu=$ effect of the general mean; $B_{i}$ $=$ effect of the $i^{\text {th }}$ block; $P_{j}=$ effect of the $i^{\text {th }}$ population; $B_{i} P_{j}$ $=$ effect $\mathrm{f}$ the $i j^{\text {th }}$ block by population interaction; $e_{i j k}=$ error.

To evaluate the relationship between plant performance variables and altitude, climate and transfer values of the provenances, a linear regression analysis or quadratic analysis were carried out with the following linear and quadratic models, respectively.

$$
\begin{gathered}
Y_{i j}=\beta_{0}+\beta_{1} X_{i}+e_{i j} \\
Y_{i j}=\beta_{0}+\beta_{1} X+\beta_{2} X_{i}^{2}+e_{i j}
\end{gathered}
$$

where $Y_{i j}=$ population mean; $\beta_{0}=$ intercept; $\beta_{1}=$ slope; $X_{i}$ $=$ altitude or climate value of the $i^{\text {th }}$ provenance; $e_{i j}=$ error.

\section{Results and Discussion}

\section{Contemporary and future climates of the provenances}

Contemporary climate (1961-1990) estimations for each provenance indicate an altitudinal pattern of the climate variables temperature, degree-days, and aridity index, where higher elevation provenances have lower temperature, degree-days and aridity index (low AAI values indicate a colder humid climate) and provenances at lower elevation have higher temperatures, degree-days and aridity index (high AAI values indicate warmer dryer climate).
The differences between contemporary precipitation of the higher sites and that at lower sites is minimal, approximately $20 \mathrm{~mm}$ (1.6\% of the annual average) (Figure 1), and between the L. elegans provenance of highest precipitation and that of lowest precipitation, the difference is $75 \mathrm{~mm}$ ( $6.1 \%$ of the annual average). However, when temperature is higher at lower altitudes, the water balance is less favorable for the plant, compared with that of a site at a higher elevation with lower temperature and equal precipitation; this is because evapotranspiration is higher in a warmer site (Allen et al., 2006). That is, the lack of differences in precipitation should not lead to the conclusion that there is no gradient in moisture availability for the plant. A gradient does exist, since precipitation in the study region does not increase in parallel to the temperature increment (as result of a decrease in altitude).

Averaging the estimation of the six scenario-models, for the year 2030 it is expected to find (averaging the climate estimates for the six provenances) increments of $1.4{ }^{\circ} \mathrm{C}$ in mean annual temperature and, of 518 degree-days in thermal units, coupled to a decrease in precipitation of $90 \mathrm{~mm}$ (-7.3\% of contemporary precipitation) and an increase in the aridity index of 0.0077 (Figure 1).

In synthesis, the sites occupied by the current populations of L. elegans will have a warmer and drier climate in the year 2030, creating an adaptive lag between forest populations and the climate to which they are adapted (Rehfeldt et al., 2012).

\section{Differences between sites and between populations}

The analysis of variance that included the two field sites (Table 2) did not reveal any statistically significant differences between sites nor between populations for any variable. However, there were large significant differences for the site $x$ population interaction for height growth $(\mathrm{P}<0.0001)$, aerial biomass $(\mathrm{P}<0.0001)$ and survival $(\mathrm{P}=0.0006)(\mathrm{Ta}-$ ble 2). The contribution of this interaction to total variance was: $34.8 \%$ for plant height growth, $23.4 \%$ for biomass and $7.0 \%$ for survival. This fact reduces statistical power to find significant differences between sites and populations since the site $\mathrm{x}$ population term of the model is part of the error and, for population it is in itself the term of error in determining the significance of site and population, respectively (e.g., Sáenz-Romero et al., 2001). For this reason, we decided to perform an analysis of variance for each site.

Contrasting with the results of the ANOVA that included the two sites, the ANOVA for each site detected significant differences among populations for practically all the variables in both sites $(\mathrm{P}<0.04$; except for plant height in the $2600 \mathrm{~m}$ site where $\mathrm{P}=0.0615$ ) (Table 3 ). 

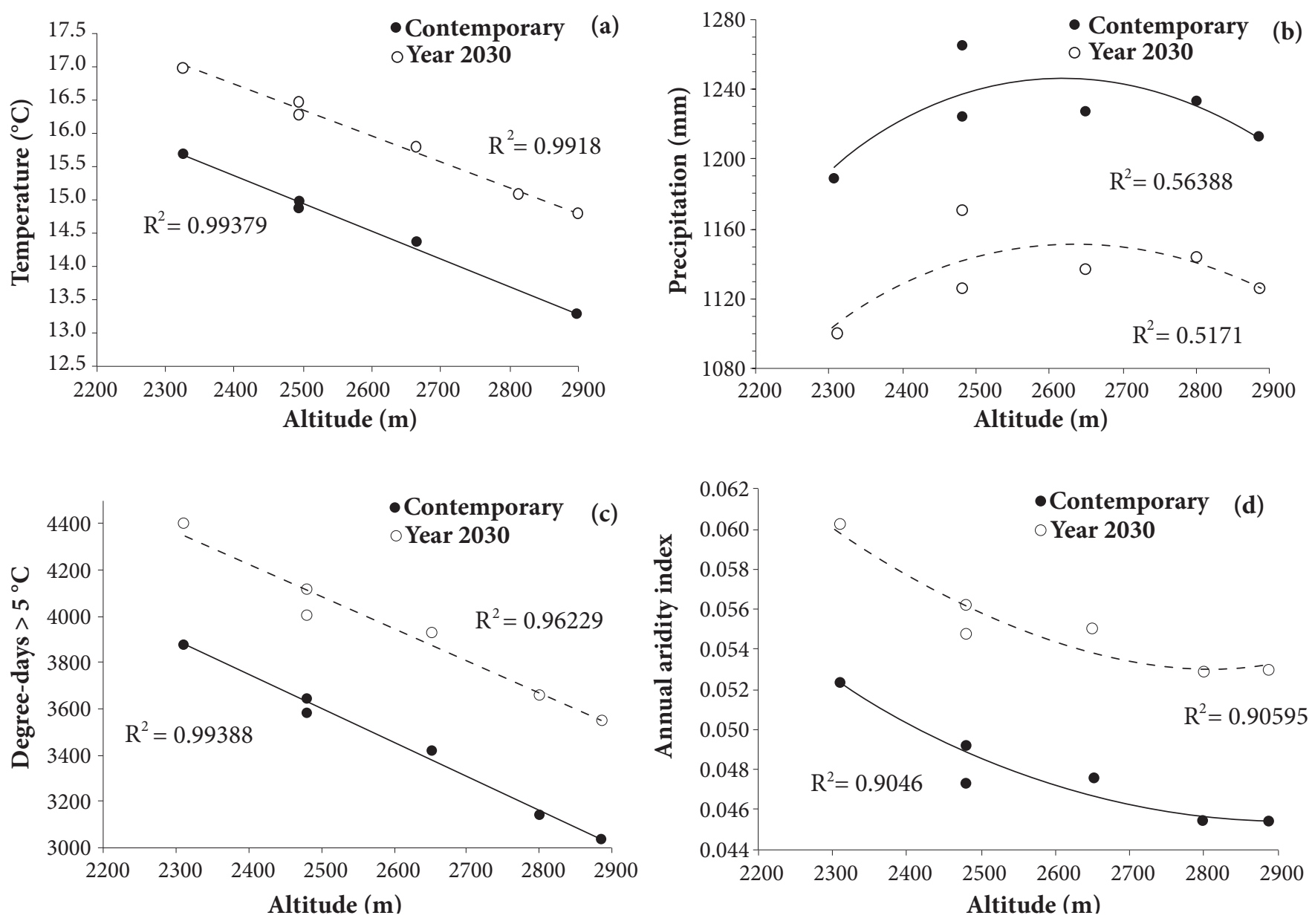

Figure 1. Mean annual temperature (a), mean annual precipitation $(\mathrm{mm})(\mathrm{b})$, degree-days $>5^{\circ} \mathrm{C}(\mathrm{c})$, and aridity index [index $=\left(\text { degree-days }>5^{\circ} \mathrm{C}\right)^{0.5} /$ mean annual precipitation $\left.(\mathrm{mm})\right](\mathrm{d})$, estimated for contemporary climate (average 1961-1990) and for climate of the decade centered in the year 2030 (average of six emissions models), for the provenances of Lupinus elegans collected along an altitudinal gradient in the Mil Cumbres region of Michoacán, México.

The among-population variation pattern for plant height and biomass was highly different in each field site, depending on the altitude at which the populations were tested. This is easier to visualize when plant performance (survival, plant height or aerial dry weight) is plotted against the difference in altitude or difference in climate between the site of origin of the population (the provenance) and the experimental site (the transfer distance value), for each experimental site (Figure 2).

In general terms, when trees were planted at lower altitude (2600 $\mathrm{m}$ site), the populations grew less and did not exhibit a definite pattern that depended on their altitude or climate of origin (non-significant regressions in the left column of panels in Figure 2; only aerial biomass is shown, but plant height pattern is very similar).
In contrast, when planting was done at the higher elevation $(2800 \mathrm{~m})$, a clearly defined pattern appeared: plants derived from populations growing at the higher altitude (colder and more humid sites, negative transfer values for altitude, positive for temperature or aridity index) grew higher and produced more biomass. On the other hand, plants from populations growing at low altitude (warmer and drier sites, positive transfer values for altitude, negative for temperature or aridity index) were shorter and had less biomass (right column of panels in Figure 2).

Significant association was found between aerial biomass and transfer distance, expressed as altitude $\left(\mathrm{R}^{2}=0.86, \mathrm{P}=\right.$ $0.0286)$, mean annual temperature $\left(R^{2}=0.85, P=0.0302\right)$ or aridity index $\left(\mathrm{R}^{2}=0.94, \mathrm{P}=0.0056\right)$ (Figure 2$)$. The pattern of variation among populations is very similar for plant 
Table 2. Analysis of variance (contribution to total variance, in \%; significance, in $\mathrm{P}$ ) for height growth, aerial part dry weight and survival of 12-month-old plants from six Lupinus elegans populations tested in common garden tests in two sites at the Mil Cumbres region, Michoacán, México.

\begin{tabular}{|c|c|c|c|c|c|c|c|}
\hline \multirow{2}{*}{ Source of Variation } & \multirow{2}{*}{ d.f. } & \multicolumn{2}{|c|}{ Height } & \multicolumn{2}{|c|}{ Dry weight } & \multicolumn{2}{|c|}{ Survival } \\
\hline & & $\%$ & $\mathrm{P}$ & $\%$ & $\mathrm{P}$ & $\%$ & $\mathrm{P}$ \\
\hline Site & 1 & 5.15 & 0.2245 & 6.35 & 0.1855 & 1.11 & 0.2367 \\
\hline Block (Site) & 22 & 1.02 & 0.7546 & 1.39 & 0.0840 & 2.14 & 0.0685 \\
\hline Population & 5 & 6.45 & 0.4004 & 9.02 & 0.3030 & 4.14 & 0.2497 \\
\hline Site $\mathrm{x}$ Population & 5 & 34.81 & 0.0001 & 23.36 & 0.0001 & 7.09 & 0.0006 \\
\hline Block x Population (Site) & $\mathrm{a}$ & 2.68 & 0.1306 & 0.00 & 0.8989 & 7.22 & 0.0032 \\
\hline Error & $\mathrm{b}$ & 49.89 & & 59.88 & & 78.3 & \\
\hline
\end{tabular}

Degrees of freedom (d.f.) in a: for height $=99$; dry weight $=92$; survival $=110$; in b: for height $=278$; dry weight $=252$; survival $=572$.

Table 3. Analysis of variance by site (contribution to total variance, in \%; significance, in $\mathrm{P}$ ) of height growth, aerial biomass and survival of 12-month-old plants from six populations of Lupinus elegans tested in common gardens at the Mil Cumbres region, Michoacán, México.

\begin{tabular}{|c|c|c|c|c|c|c|c|}
\hline \multirow{3}{*}{ Source of variation } & \multirow{3}{*}{ d.f. } & \multicolumn{6}{|c|}{$2800 \mathrm{~m}$ altitude site } \\
\hline & & \multicolumn{2}{|c|}{ Height } & \multicolumn{2}{|c|}{ Dry weight } & \multicolumn{2}{|c|}{ Survival } \\
\hline & & $\%$ & $\mathrm{P}$ & $\%$ & $\mathrm{P}$ & $\%$ & $\mathrm{P}$ \\
\hline Block & 11 & 1.6 & 0.7471 & 1.4 & 0.1912 & 0.0 & 0.0921 \\
\hline Population & 5 & 51.2 & 0.0001 & 33.6 & 0.0001 & 6.7 & 0.0001 \\
\hline Block x Population & $\mathrm{a}$ & 0.0 & 0.5525 & 0.3 & 0.8126 & 14.4 & 0.1490 \\
\hline \multirow[t]{4}{*}{ Error } & $\mathrm{b}$ & 47.3 & & 64.6 & & 79.0 & \\
\hline & & & & \multicolumn{2}{|c|}{$2600 \mathrm{~m}$ altitude site } & & \\
\hline & & \multicolumn{2}{|c|}{ Height } & \multicolumn{2}{|c|}{ Dry weight } & \multicolumn{2}{|c|}{ Survival } \\
\hline & & $\%$ & $\mathrm{P}$ & $\%$ & $\mathrm{P}$ & $\%$ & $\mathrm{P}$ \\
\hline Block & 11 & 0.3 & 0.5342 & 0.3 & 0.3375 & 11.8 & 0.1790 \\
\hline Population & 5 & 4.0 & 0.0615 & 14.9 & 0.0001 & 22.1 & 0.0349 \\
\hline Block x Population & $\mathrm{a}$ & 14.9 & 0.016 & 0.0 & 0.9884 & 66.1 & 0.0029 \\
\hline Error & $\mathrm{b}$ & 80.8 & & 84.7 & & 0.0 & \\
\hline
\end{tabular}

d.f. $=$ degrees of freedom in site at $2800 \mathrm{~m}$ in a: for height $=48$, dry weight $=42$, survival $=55$; in b: height $=120$ dry weight $=107$; survival $=287$. In site at 2600 $\mathrm{m}$ in a: for height $=51$, dry weight $=50$, survival $=55$; in b: height $=158$, dry weight $=145$, survival $=285$.

height, with a significant association with transfer distance in altitude $\left(\mathrm{R}^{2}=0.90, \mathrm{P}=0.0150\right)$, mean annual temperature $\left(\mathrm{R}^{2}=0.89, \mathrm{P}=0.0163\right)$ or aridity index $\left(\mathrm{R}^{2}=0.96, \mathrm{P}=\right.$ $0.0094)$; this similarity can be explained by the high correlation existing between this index and aerial biomass $(\mathrm{r}=$ $0.77, \mathrm{P}<0.001)$.

This pattern of altitudinal clinal variation is similar to that found in a field experiment (planted directly in forest soil) at an altitude of $2700 \mathrm{~m}$ (Soto-Correa et al., 2012). This pattern indicates that populations have differentiated genetically to adapt to a portion of the environmental gradient occupied by the species (Rehfeldt, 1989; Viveros-Viveros et al., 2009; Vitasse et al., 2009b). These results are also in line with morphological differentiation among populations for Lupinus angustifolius traits, which showed a pattern of variation associated with climatic differences among sites in which its populations grow (Clements and Cowling, 1994).

Survival had a trend similar to that of plant height and biomass: there was no association with original altitude or climate when trees were planted at $2600 \mathrm{~m}$, but there was a clinal tendency when they were planted at $2800 \mathrm{~m}$. However, regressions of survival percentage against transfer distance were not significant in any case $(P \geq 0.1275)$.

These results suggest that when assisted migration of species and populations is carried out, populations may 

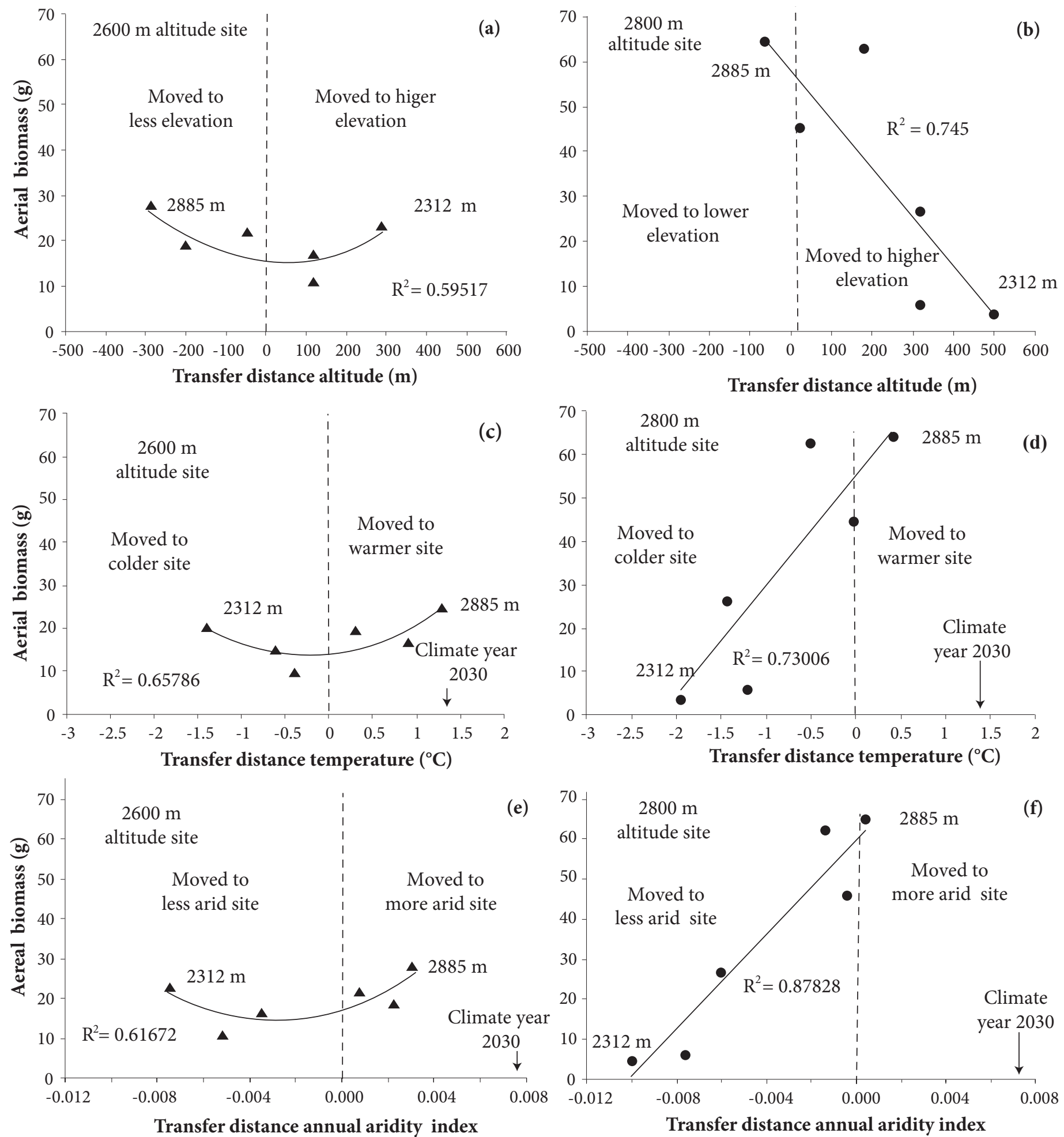

Figure 2. Average aerial biomass of Lupinus elegans population, plotted against altitudinal or climatic transfer distance (altitudinal or climatic difference between test site and provenance), expressed as difference in altitude (m), mean annual temperature $\left({ }^{\circ} \mathrm{C}\right)$ or annual aridity index [index $=\left(\text { degree-days }>5^{\circ} \mathrm{C}\right)^{0.5} /$ mean annual precipitation $(\mathrm{mm})$ ], for each test site: $2600 \mathrm{~m}$ (left column of graphs a, c, e) and $2800 \mathrm{~m}$ of altitude (right column of graphs b, d, f). Vertical broken lines indicate if seedlings were planted at local elevation or climate (zero value of transfer distance). Arrows point to the equivalence (in transfer distance) of the predicted climate for year 2030 (averaging six climatic model-scenarios). Original altitude of some populations is indicated. 
have different patterns of variation, depending on the site altitude. This could be due to how populations respond to different site temperatures since their ability to adapt may be different (Vitasse et al., 2009a). Response of L. elegans populations originated from the same altitudinal transect than in this study when exposed to extreme low temperatures (population showed genetic differentiation among populations along the altitudinal gradient), than when exposed to extreme high temperatures (all populations were equally susceptible). This indicates a larger potential to adapt to extreme colder temperatures than to extreme higher temperatures (Soto-Correa et al., 2013).

In terms of population performance, it is notable that when one population with better growth, as the one originating at $2885 \mathrm{~m}$, grew in the $2800 \mathrm{~m}$ site (an altitude similar to its original site, near to zero transfer value), it accumulated an average of $63.6 \mathrm{~g}$ biomass of dry weight, while when it grew in the $2600 \mathrm{~m}$ site ( $285 \mathrm{~m}$ lower elevation than its original site, $1.2^{\circ} \mathrm{C}$ warmer), it accumulated only $28.3 \mathrm{~g}$ biomass (less than half of the accumulated biomass at 2800 m) (Figure 2 a-d).

Thus, an increase in temperature will slow down growth of L. elegans, at least in some populations from high altitude. This also provides an estimation of the possible effect of climate change for the year 2030, because transferring the population from 2885 to the $2600 \mathrm{~m}$ site (an altitude $285 \mathrm{~m}$ lower), is almost equivalent to the global warming predicted for 2030: an increase of $1.4^{\circ} \mathrm{C}$ (Figure $2 \mathrm{a}-\mathrm{d}$ ).

If temperature and precipitation are considered simultaneously and expressed in values of the annual aridity index, the climate change would induce increasingly arid conditions, relative to current aridity in the $2600 \mathrm{~m}$ site (see equivalence in transfer distance for both sites, Figure $2 \mathrm{e}-\mathrm{f}$ ). Thus, it is reasonable to assume that if temperature increase is combined with less rainfall, some L. elegans high altitude populations will diminish their growth, even more than that exhibited by the population originated at $2885 \mathrm{~m}$ of elevation, after it was transferred to the $2600 \mathrm{~m}$ elevation site.

The pattern was different for the lower altitude population (originated at $2312 \mathrm{~m}$ ). When it grew in the lower elevation site $(2600 \mathrm{~m})$, it accumulated an average of $22.6 \mathrm{~g}$ of dry weight, while when it grew at $2800 \mathrm{~m}$ site it accumulated only $3.7 \mathrm{~g}$ of biomass (almost five times less) (Figure $2 \mathrm{a}-\mathrm{b}$ ). That is, growing at conditions $1.9^{\circ} \mathrm{C}$ colder than its original site caused a notable decrease in growth rate (Figure c-d).

The growth reduction observed in the transferred popu- lations, either to a warmer site or to a colder site, is the result of suboptimal conditions for optimal plant physiology (Levitt, 1980). When transferred to a higher altitude, plants were subjected to cold stress, while plants transferred to a lower elevation suffered from heat stress. The farther their transfer distance, the less they will grow.

The mentioned results lead to conclude that if the high altitude L. elegans populations remain in their sites of origin, their growth will decrease as a consequence of the stress caused by global warming. Low altitude populations migrated to higher altitudes with human assistance will also undergo a decrease in growth at the beginning since immediately after migration they will be in a colder climate. However, if assisted migration is not done, all the populations would deteriorate under future climate conditions. Thus, it seems reasonable to assist migration to environments for which they are currently adapted (Rice and Emery, 2003; McLachlan et al., 2007), which will occur at higher altitudes in the future. Because of the genetic differentiation among populations and their diverse responses to the environmental conditions of the sites where they are planted, the assisted migration should be gradual, in upward altitude movements of $150 \mathrm{~m}$ at intervals of six years, as proposed by Soto-Correa et al., (2012).

Caveat for this research

The contrasting population performance patterns, which clearly depend on the field test site altitudes, highlights the need of future experiments with a larger number of field tests sites and more contrasting climatic conditions. Our results from only two field sites might represent a limited portion of a larger response patterns due to a larger array of possible climatic conditions in numerous field sites.

It would be specially interesting to establish provenance tests at the extreme-low altitude limits of the contemporary distribution, where the "rear end" contemporary populations will suffer the temperatures increases most, due to ongoing climatic change (Fetting et al., 2013), because they are already in their xeric limit (Mátyás, 2010).

\section{CONCLUSIONS}

Estimations by climate models predict an average increase of $1.4^{\circ} \mathrm{C}$ in mean annual temperature, equivalent to 518 degree-days, a reduction of $90 \mathrm{~mm}$ in precipitation (-7.3\% of contemporary precipitation), and an increase of 0.0077 in annual aridity index by the year 2030 .

Large significant differences were found in the interaction between site and populations for plant height, dry weight and survival. 
Genetic differentiation among populations is expressed in very distinct patterns, depending on the test site altitude. In the high altitude site $(2800 \mathrm{~m})$, plant height and biomass are strongly associated with transfer distance (altitudinal or climatic) between place of origin and experimental site. Plants from higher altitude populations can grow more than those from lower altitude populations. In contrast, in the lower elevation site $(2600 \mathrm{~m})$, although there were significant or almost significant differences between populations, there was no clinal pattern.

In general, populations grew less when they were moved away from the climate where they originated. This indicates that climate change will likely induce less growth in several populations, so assisted migration should be done gradually.

\section{ACKNOWLEDGEMENTS}

To the Fondo Mixto CONACyT-Michoacán (FOMIX 2009-127128), to the Coordinación de Investigación Científica of the UMSNH, and to the PAPIIT program of the UNAM for funding this study. We also thank Horacio Paz, Erick de la Barrera (CIEco-UNAM), Nahum Sánchez (IIAF-UMSNH), José Cruz de León (FITECMA-UMSNH), as well as two anonymous reviewers, one associated editor and one editor of style, for their valuable comments which significantly contributed to improving the manuscript.

\section{BIBLIOGRAPHY}

Aitken S. N., S. Yeaman, J. A. Holliday, T. Wang and S. Curtis-McLane (2008) Adaptation, migration or extirpation: climate change outcomes for tree populations. Evolutionary Applications 1:95111.

Allen R. G., L. S. Pereira, D. Raes and M. Smith (2006) Crop Evapotranspiration; Guidelines for Computing Crop Water Requirements. FAO Irrigation and Drainage Paper No. 56. Rome, Italy, FAO. $174 \mathrm{p}$.

Alvarado-Sosa A., P. Blanco-García and R. Lindig-Cisneros (2007) Test of alternative nursery propagation conditions for Lupinus elegans Kunth plants, and effects on field survival. Revista Fitotecnia Mexicana 30:201-204.

Benowicz A., S. L'Hirondelle and Y. A. El-Kassaby (2001) Patterns of genetic variation in mountain hemlock (Tsuga mertenstana (Bong) Carr.) with respect to height growth and hardiness. Forest Ecology and Management 154:23-33.

Blanco-García A., C. Sáenz-Romero, C. Martorell, P. Alvarado-Sosa and R. Lindig-Cisneros (2011) Nurse plant and mulching effects on three conifer species in a Mexican temperate forest. Ecological Engineering 37:994-998.

Clements J. and A. Cowling (1994) Patterns of morphological diversity in relation to geographical origins of wild Lupinus angustifolius from the aegean region. Genetic Resources and Crop Evolution 41:109-122.

Crookston N. L. and G. E. Rehfeldt (2011) Research on Forest Climate Change: Potential Effects of Global Warming on Forests and Plant Climate Relationships in Western North America and Mexico. Available at http://forest.moscowfsl.wsu.edu/climate/ (April 2011).

Devall M. S. (2009) Efectos del cambio climático mundial en los árboles y arbustos raros Unasylva 60:231-232.

Dunn D. B. (2001) Lupinus. In: Flora Fanerogámica del Valle de México.
R. G. Calderón y J. Rzedowski (eds).. Ed. Instituto de Ecología, A. C., CONABIO. Pátzcuaro, Michoacán México. pp:290-300.

Fettig C. J., M. L. Reid, B. J. Bentz, S. Sevanto, D. L. Spittlehouse and T. Wang (2013) Changing climates, changing forests: a western North American perspective. Journal of Forestry 111:214-228.

Lara-Cabrera S., N. Alejandre-Melena, E. Medina-Sánchez and R. Lindig-Cisneros (2009) Genetic diversity in populations of Lupinus elegans Kunth, implications for ecological restoration. Revista Fitotecnia Mexicana 32:79-86.

Leites L. P., A. P. Robinson, G. E. Rehfeldt, J. D. Marshall and N. L. Crookston (2012) Height-growth response to climatic chang es differs among populations of Douglas-fir: a novel analysis of historic data. Ecological Applications 22:154-165.

Levitt J. (1980) Responses of Plants to Environmental Stresses. Academic Press, New York. 607 p.

Lindig-Cisneros R., A. Blanco-García, C. Sáenz-Romero, P. AlvaradoSosa y N. Alejandre-Melena (2007) Restauración adaptable en la meseta Purépecha, Michoacán, México: hacia un modelo de estados de transiciones. Boletín de la Sociedad Botánica de México 80:25-31.

Mátyás C. (2010) Forecasts needed for retreating forests. Nature 464:1271

Mátyás C., I. Berki, B. Czúcz, B. Gálos, N. Móricz and E. Rasztovits (2010) Future of beech in Southern Europe from the perspective of evolutionary ecology. Acta Silvatica and Lingaria Hungarica 6:91-110.

McDowell N. G., W. T. Pockman, C. Allen, D. D. Breshears, N. Cobb, T. Kolb, J. Plaut, J. Sperry, A. West, D. G. Williams and E. A. Yepez (2008) Mechanisms of plant survival and mortality during drought: why do some plants survive while others succumb to drought? New Phytologist 178:719-739.

McLachlan S. J., J. S. Clark and P. S. Manos (2005) Molecular indicators of tree migration capacity under rapid climate change. Ecology 86:2088-2098.

McLachlan J., J. J. Hellmann and M. W. Schwartz (2007) A framework for debate of assisted migration in an era of climate change. Conservation Biology 21:297-302.

Medina-Sánchez E. I. and R. Lindig-Cisneros (2005) Effect of scarification and growing media on seed germination of Lupinus elegans. H. B. K. Seed Science and Technology 33:237-241.

Oleskyn J., P. B. Reich, M. G. Tjoelker and W. Chalupka (2001) Biogeographic differences in shoot elongation pattern among European Scots pine populations. Forest Ecology and Management 148:207-220.

Pearson R. G. (2006) Climate change and the migration capacity of species. Trends in Ecology and Evolution 21:111-113.

Rehfeldt G. E. (1988) Ecological genetics of Pinus contorta from the Rocky Mountains (USA): a synthesis. Silvae Genetica 37:131-135.

Rehfeldt G. E. (1989) Ecological adaptations in Douglas-fir (Pseudotsuga menzienssii var. Glauca): a synthesis. Forest Ecology and Management 28:203-215.

Rehfeldt G. E. (2006) A Spline Model of Climate for the Western United States. General Technical Report RMRS-GTR-165. Fort Collins, Colorado, U.S. Department of Agriculture, Forest Service, Rocky Mountain Research Station. 21 p.

Rehfeldt G. E., N. L. Crookston, M. V. Warwell and J. S. Evans (2006) Empirical analyses of plant-climate relationships for the western United States. International Journal of Plant Sciences 167:1123-1150.

Rehfeldt G. E., N. L. Crookston, C. Sáenz-Romero and E. Campbell (2012) North American vegetation model for land-use plan ning in a changing climate: a solution to large classification problems. Ecological Applications 22:119-141.

Rice K. J. and N. C. Emery (2003) Managing microevolution: restoration in the face of global change. Frontiers in Ecology and the Environment 1:469-478.

Sáenz-Romero C., E. V. Nordheim, R. P. Guries and P. M. Crump (2001) A case study of a provenance/progeny test using trend analysis with correlated errors and SAS PROC MIXED. Silvae Genetica 50:127-135.

Sáenz-Romero C., G. E. Rehfeldt, N. L. Crookston, P. Duval, R. StAmant, J. Beaulieu and B. A. Richardson (2010) Spline models of contemporary, 2030, 2060 and 2090 climates for Mexico and their use in understanding climate-change impacts on the 
vegetation. Climatic Change 102:595-623.

Sáenz-Romero C., G. E. Rehfeldt, P. Duval and R. Lindig-Cisneros (2012a) Abies religiosa habitat prediction in climatic change scenarios and implications for monarch butterfly conservation in Mexico. Forest Ecology and Management 275:98-106.

Sáenz-Romero C., G. E. Rehfeldt, J. C. Soto-Correa, S. Aguilar-Aguilar, V. Zamarripa-Morales and J. López-Upton (2012b) Altitudinal genetic variation among Pinus pseudostrobus populations from Michoacán, México; two location shadehouse test results. Revista Fitotecnia Mexicana 35:111-120.

Sánchez O. (1980) La flora del Valle de México. Ed. Herrero. México D. F. 519 p.

SAS Institute Inc. (2004) SAS/ STAT 9.1 User's Guide. SAS Institute Inc., Cary, North Carolina. 5136 p.

Soto-Correa J. C., C. Sáenz-Romero, R. Lindig-Cisneros, N. SánchezVargas and J. Cruz-de-León (2012) Genetic variation between Lupinus elegans Kunth provenances, altitudinal seed zonning and assisted migration. Agrociencia 46:593-608.

Soto-Correa J. C., C. Sáenz-Romero, R. Lindig-Cisneros and E. de-laBarrera (2013) The neotropical shrub Lupinus elegans, from temperate forests, may not acclimate to climate. Plant Biology
15:607-610.

Tchebakova N. M., G. E. Rehfeldt and I. E. Parfenova (2005) Impacts of climate change on the distribution of Larix spp. and Pinus sylvestris and their climatypes in Siberia. Mitigation and Adaptation Strategies for Global Change 11:861-882.

Thomas S. C. (2011) Genetic vs phenotypic responses of trees to altitude. Tree Physiology 31:1161-1163.

Vitasse Y., S. Delzon, E. Dufrêne, J. T. Pontailler, J. M. Louvet, A. Kremer and R. Michalet (2009a) Leaf phenology sensitivity to temperature in European trees : Do within-species populations exhibit similar response?. Agricultural and Forest Meteorology 149:735-744.

Vitasse Y., S. Delzon, C. C. Bresson, R. Michalet and A. Kremer (2009b) Altitudinal differentiation in growth and phenology among populations of temperate-zone tree species growing in a common garden. Canadian Journal of Forest Research 39:1259-2009.

Viveros-Viveros H., C. Sáenz-Romero, J. J. Vargas-Hernández, J. LópezUpton, G. Ramírez-Valverde and A. Santacruz-Valera (2009) Altitudinal genetic variation in Pinus hartwegii Lindl. I: Height growth, shoot phenology, and frost damage in seedlings. Forest Ecology and Management 257:836-842. 